\title{
VLADIMIR KHAZAN
}

The Hebrew University of Jerusalem (Jerusalem, Israel)

\section{«Наше дело нажимать, не давать успокоиться, продолжать бескомпромиссную борьбу против существующего зиа». Переписка Юлия Марголина и Марка Вишняка Часть первая ${ }^{1}$}

\begin{abstract}
„Nasze zadanie polega na wywieraniu presji, wywoływaniu stałego niepokoju, na ciągłej bezkompromisowej walce ze złem". Korespondencja Julija Margolina z Markiem Wiszniakiem

(zęść pierwsza (część druga ukaże się w kolejnym numerze)
\end{abstract}

Streszczenie: Celem publikacji korespondencji Marka Wiszniaka (1883-1976) — rosyjskiego historyka, publicysty, pamiętnikarza, działacza społeczno-politycznego, prominentnego członka partii eserów isekretarza zlikwidowanej przez bolszewików Konstytuanty z Julijem Margolinem (1900-1974) — dziennikarzem, pisarzem, poetą, filozofem politycznym, krytykiem literackim, antykomunistą i zagorzałym przeciwnikiem totalitaryzmów jest: a) poszerzenie wiedzy na temat ich indywidualnych toposów biograficznych i powiązania ich z wydarzeniami „wielkiej” historii; b) wykazanie ścisłego związku rosyjskojęzycznej kultury Izraela ze światową żydowską diasporą emigrantów rosyjskich; c) dobitne podkreślenie faktu, że istniejąca najpierw w Palestynie, a następnie w Izraelu rosyjskojęzyczna literatura stanowi nieodłączną część ogólnoświatowego zjawiska literackiego, zwanego Russia Abroad.

Słowa kluczowe: Izrael, syjonizm, Żydzi rosyjscy, totalitarno-obozowy reżim komunistyczny, wolność

"Our object is to press, not to let you relax, continue the uncompromising fightagainst existing evil". Correspondence between Yuliy Margolin and Mark Vishniak.

First part (final part will be published in the next issue)

Summary: Publication of the correspondence of the Russian historian, publicist, memoirist, public and political figure, a prominent member of the Socialist-Revolutionary Party, secretary of the All Russian Constituent Assembly dispersed by the Bolsheviks Mark Vishniak (1883-1976) with journalist, writer, poet, political philosopher and literary critic, anticommunist and violent fighter against totalitarianism Yuliy Margolin (19001971) pursues several important points: a) to expand the understanding of the individual biographical toposes

1 В этом номере публикуется первая часть статьи, вторая ожидается в следующем. Автор данной работы выражает искреннюю признательность своим друзьям и коллегам - Ларисе Жуховицкой (Москва) и Гилю Вейсблею (Иерусалим). 
of both and to connect them with the events of the "big" history; b) to demonstrate the close connection of the Russian-language culture of Israel with the world Jewish diaspora of emigrants from Russia; c) to strengthen in every possible way the significant fact that the Russian-speaking literature, which existed in Mandatory Palestine and is developing today in modern Israel is an integral part of the global literary process associated with the phenomenon of Russia Abroad.

Keywords: Israel, Zionism, Russian Jewishness, totalitarian-camp regime, freedom

Подробно представлять авторов нижепубликуемой переписки, как кажется, нет особой необходимости. Имя историка, публициста, мемуариста, общественно-политического деятеля, видного члена партии социалистов-революционеров Марка Вениаминовича Вишняка (1883-1976) широко известно - и как автора многочисленных книг и статей по разнообразным проблемам политической истории и международного права, и как одного из редакторов самого крупного в русской эмиграции между двумя мировыми войнами журнала «Современные записки», и, если пойти вглубь времен - секретаря разогнанного большевиками Учредительного собрания. Что же касается журналиста, писателя, поэта, политического философа, литературного критика, бесстрашного и неистового борца с коммунизмом и тоталитаризмом, в какие бы одежды они ни рядились и какие бы формы ни принимали, Юлия Борисовича Марголина (1900-1971), то его жизнь, деятельность и творчество давно заслужили капитального и всестороннего исследования. Такое исследование должно было бы и указать на его роль в современной истории борьбы с коммунистическими идолами, и определить место в литературе, посвященной лагерной теме, и, что не менее важно, положить конец разного рода отсебятинам, которые обычно расцветают там, где и когда зияют биографические лакуны и то или иное лицо не введено в «канон» общеобязательного современного знания.

Один только пример в подтверждение сказанному. В недавней книге, собравшей под своей обложкой творческое наследие поэта и критика Владимира Злобина, литературного секретаря Дмитрия Мережковского и Зинаиды Гиппиус, в краткой справке о Марголине произвольно указывается, что его сестрами были Ольга (последняя жена Владислава Ходасевича) и Марианна Марголины, погибшие в Аушвице $^{2}$. Это совершенно произвольное и ложное утверждение, брошенное небрежно и походя и не опирающееся ровным

2 В.А. Злобин, Тяжелая душа: Литературный дневник, воспоминания, статьи, стихотворения (ред. Л.М. (урис), Директ-Медиа, Москва-Берлин 2016, с. 89. 
счетом ни на какие документальные свидетельства, едва ли могло бы быть сделано в отношении человека, чья биография оказалась бы презумпированной надежной фактографией.

Последняя, среди прочего, должна создать преграду для некритического принятия на веру ошибочных мемуарных свидетельств, как, скажем, утверждение Романа Гуля, знакомого с Марголиным с берлинских времен, т.е. с начала 20-х гг., будто бы он привлек Юлия Борисовича к сотрудничеству в сменовеховской газете «Накануне»³, в которой тот, на самом деле, никогда не печатался.

Начиная с главной книги своей жизни - Путешествие в страну Зе-Ка (1952), написанной как свидетельство человека, прошедшего все круги советского лагерного ада, до многих сотен других текстов - публицистических и художественных, напечатанных на разных языках и в многочисленных изданиях, имеющих весьма широкую географию - Израиль, США, Европа, Марголин заслужил безусловное право на внимание как со стороны массового читателя, так и более специального научного изучения. Так, в частности, совершенно неизвестным остается его эпистолярное наследие, которое, с одной стороны, проливает свет на сложность и неординарность этой личности, с другой же, служит серьезному и значительному расширению и углублению информационной базы его жизни и деятельности и, наконец, устанавливает твердые и отчетливые коммуникации с историческим контекстом. В этом смысле письма Марголина или к нему не в меньшей степени, нежели его статьи и книги, дают обширный материал для обнаружения новых связей и завязей частной человеческой и творческой биографии и «большой» истории.

Одним из весьма значимых аспектов публикации эпистолярных материалов является, как правило, раскрывающийся через них круг общения автора (или авторов) писем, то социальное milieu, которое крайне сложно установить и детально восстановить посредством других биографических документов. В случае с Марголиным это в особенности существенно, поскольку, если не считать его поездок в другие страны (что, кстати сказать, тоже можно проследить благодаря письмам),

3 Р.Б. Гуль, Я унес Россию: Апология эмиграции, т. 1: Россия в Германии, Ю.С.Г.-ПРЕСС, Москва 2001, c. 248. 
основное время после освобождения из советского концлагеря (июнь 1945) и приезда в Израиль (сентябрь-октябрь 1946) он провел вне широкого социального контакта с русским языком и деятелями русской культуры, оставаясь в то же время по своему духу и творческой природе их неотъемлемой частью. Вот почему, когда через письма конкретизируется персоналитет Марголина - его друзья, приятели и идейные единомышленники, чьи имена являются знаковыми для истории русской духовной жизни в изгнании, многое проясняется и в его собственной истории как человека и как носителя творческого - политического, философского, художественного - сознания.

Дело, разумеется, не сводится исключительно к именной конкретизации умственной среды Марголина, его коллег по творческому цеху, и не к экстенсивному расширению, так сказать, их списочного состава, более глубокий пласт проблематики видится в ином - в выявлении содержания и форм их корреспондирования и взаимодействия между собой, стиранию географических границ, сокращению пространственных расстояний и образованию единой духовно-интеллектуальной сообщности. И здесь случай Марголина становится весьма симптоматичным. Эта симптоматика прежде всего проявляет себя в том, что русскоязычный Израиль делается такой же частью разбредшейся по миру, но не разобщенной русской литературы. Абсолютная очевидность этого положения пока лишь в самой начальной форме подкреплена адекватными научными исследованиями.

Это одна сторона проблемы, выразительно, как думается, проявляющаяся в публикуемых письмах. Другая же, более, если можно так выразиться, «местная», локальная, заключается вот в чем. На протяжении примерно последних ста лет в сионизме идет непрекращающаяся партийно-идеологическая борьба левого (условно говоря, социалистического, «бен-гурионовского») и правого (ревизионистского, восходящего к Жаботинскому и его последователям) лагерей. Марголин, который формально не принадлежал ни к одной партии, занимал в этом противостоянии четко выраженные правые позиции. Самобытность его политических воззрений, однако, при всем их нередком радикализме никогда не покидала рамок интеллектуализма и либерализма самой высокой пробы. Поэтому его диалог с Вишняком, в определенном смысле прямым идейным оппонентом, который, с одной стороны, являлся типом левого социалиста-либерала, еврея-несиони- 
ста, сочувствующего Израилю4, приобретает значение, выходящее далеко за границы частной переписки двух интеллектуалов. Становясь по-своему выразительным знамением того времени, в которое жили оба корреспондента, этот диалог, как представляется, не потерял своей живой актуальности до сегодняшнего дня. В этом смысле весьма показательным и поучительным является одно из кульминационных мест публикуемой переписки - письмо №9 9 (Вишняка) и ответему Марголина (письмо № 10), в котором последний объясняет основные мотивы, подвигнувшие его написать Еврейскую повесть.

Я совершенно один в Израиле, - пишет он Вишняку, усмотревшему в Еврейской повести политический крен в узкую фракционность и именно поэтому расценившему ее как творческую неудачу. - Какая там "фракционность"? Надо видеть человеческую сторону этого дела. Сролик - живой человек. Фанатизм и ослепление разлиты по всем евр<ейским> партиям, но из всех его форм эта - иргунская - была, накануне Катастрофы, еще наиболее оправданной. Вы не жили тогда в Польше среди миллионов в тупике. Люди чувствовали, что идет беда, дергались, искали выхода. Надо их пожалеть, даже с их ошибками.

Это объяснение многое раскрывает в пристрастной беспристрастности Марголина-писателя, с одной стороны, безусловно, не относившегося к типу творческого деятеля, стоящего над «схваткой», а непосредственно участвовавшего в ней, а с другой, стремившегося к высвобождению задач литературы из цепких лап партийной (или любой другой «цеховой») принадлежности и горячей злободневности, ограничивающих ее духовно-культурную и общественно-эстетическую роль.

Мы доподлинно не знаем, где, когда и при каких обстоятельствах произошло знакомство Марголина и Вишняка. Живший с 1940 г. в США, куда он переселился из Парижа перед угрозой его оккупации нацистами, Вишняк после войны нередко приезжал в Европу, в ту самую Францию, которая приютила

4 Свою общественно-политическую и в известном смысле нравственно-психологическую позицию по отношению к Израилю Марк Вишняк достаточно полно и недвусмысленно сформулировал в следующих словах: «Я всегда чувствовал себя русским евреем и считал, что русский еврей в условиях России XIX века особый морально-психологический тип и национально-государственная категория, которую недопустимо и, с точки зрения общей культуры нецелесообразно, чтобы не сказать 'невыгодно', расчленять и противопоставлять в ней 'еврейское' и 'русское'. Я написал множество статей, брошюр и даже две книжки, посвященные еврейским проблемам и деятелям. Побывал в Израиле трижды, но не стал приверженцем сионизма и благословлял судьбу или случай, давшие мне возможность жить вне Израиля: быть пионером в пожилом возрасте, даже в стране предков, без крайней необходимости — незавидная участь» (М. Вишняк, Годы эмиграции, 1919-1969. Париж-Нью-Йорк (Воспоминания), Stanford University: Hoover Institution Press, Stanford 1970, c. 263). 
его после бегства из большевистской ог. Скорее всего, именно в Париже, где после войны бывал и Марголин, это знакомство и должно было состояться. В любом случае, оно имело важное и плодотворное для обоих значение, и, несмотря на нередко возникавшие между ними идейные споры и поклонение далеко не во всем сходным идеологическим кумирам (о чем, в частности, свидетельствует данная переписка), возникшие между Марголиным и Вишняком человеческие отношения носили характер искреннего взаимного уважения, высокой оценки творческого капитала друг друга, не говоря уже о том, что оба принадлежали к той части русско-еврейской интеллигенции, для которой наивысшее зло воплотилось в советской коммунистической тирании.

Переходя непосредственно к переписке Марголина с Вишняком, приходится с сожалением констатировать, что она носит весьма непропорциональный характер: из 21 сохранившегося письма девятнадцать принадлежат Марголину и только два - Вишняку. Это придает публикуемому ниже эпистолярному диалогу некоторый монологический крен, хотя, как кажется сквозная интонация беседы в письмах все же присутствует.

Одновременно с этим нельзя не посетовать на то, что не все письма Марголина к Вишняку уцелели - отсутствие некоторых из них в особенности досадно: интересно, например, каков был марголинский ответ на письмо его корреспондента от 19 марта 1961 г., в котором содержалось прямое обвинение адресата в журналистской необъективности по отношению к нью-йорскому журналу «The Time», в котором Вишняк на протяжении ряда лет занимал должность сотрудника иностранного отдела.

Письма Марголина приводятся по оригиналам, а Вишняка по вторым (машинописным) экземплярам из архива последнего, хранящегося в Hoover Institution on War, Revolution, and Peace (Stanford University, CA), Mark Vishniak Coll., box 5 D.

1

Марголин - Вишняку

Тель-Авив - Тель-Авив

9 апреля 1951 [1]

Тель-Авив, 9 апр<еля > <19>51

Шенкин, 16

тел<ефон> 2398 


\section{Дорогой г. Вишняк,}

Я вернулся и очень хочу повидать Вас [2]. О том, что Вы в наших краях [3], я знал уже в Бомбее. Мне рассказал наш общий приятель Гарри Гольдберг. Я бы Вас все равно разыскал, вернувшись, и очень был рад, узнав от жены о Вашем посещении с г. Виленчуком [4]. Непременно приходите, но раньше позвоните по телефону, чтоб не разминуться.

Сердечный привет!

Ю. Марголин

\section{1. Отпечатано на машинке.}

2. Марголин участвовал в проходившем в Бомбее 28-30 марта 1951 г. Международном конгрессе в защиту свободы культуры. Человек ироничный, в том числе склонный к самоиронии, он, находясь в Бомбее, пишет себе - от имени жены - открытку, сохранившуюся в его архиве (The Central Zionist Archives (Jerusalem). А 536, folder 50); на лицевой стороне открытки, с изображением Taj Hotel, его рукой написано: «Моя резиденция»):

Сиди, старый хрен, дома и не шатайся без дела. Ну и что тебе с того, что ты обедаешь в тронном зале, с 12 мраморными колоннами под музыку? Всёсуета сует. Довольно уже, как нищему с писаной торбой, обносить свои «5 лет в лагере». Пусть бы лучше тебя чествовали за книгу новую, а не за синяк на лбу. Вот приедешь домой «с трофеями», прочти эти слова и скажи сам, неужели я не права? - Твоя Евка, которая старую гулящую няньку ждет домой поскорее, и уж тогда ни-ни. Никуда не пущу. Здесь сиди, при детях. 30/3, в полночь. БОМБЕЙ!

3. Вишняк, у которого в Тель-Авиве жила близкая родственница - родная сестра его жены, Анна Абрамовна Вишняк, (в замуж. Виленчук; 1884-?), одновременно приходившаяся ему кузиной, трижды в разные годы приезжал в Израиль. В этот раз, в 1951 г., он посетил Израиль впервые.

4. По всей видимости, речь идет об Ицхаке Виленчуке (18941974), который, репатриировавшись в Эрец-Исраэль в 1926, работал сначала как инженер (позднее, с 1930 по 1949 г. - главный инженер) в электрической компании Пинхаса Рутенберга ${ }^{5}$

5 Следует, между прочим, заметить, что Вишняк планировал попасть в Эрец-Исраэль, причем не просто с коротким визитом, а поселиться здесь навсегда, еще в 1935 г., и именно благодаря своему однопартийцу, эсеру Пинхасу Рутенбергу (1878-1942), который, репатриировавшись туда в 1919 г. и создав электрическую компанию, стал со временем одной из ведущих фигур в тамошней политико-социальной экономической жизни. Более подробно см. В. Хазан, Пинхас Рутенберг: Oт террориста к сионисту: Опыт идентификации человека, который делал историю, в 2-х томах, Гешарим-Мосты культуры, Иерусалим-Москва 2008 (об отношениях Рутенберга и Вишняка см. по индексу имен, в особенности, т. 2, с. 634-645). 
Хеврат ха-Хашмаль, а затем - главным инженером в Palestine Water Company; муж А.А. Вишняк.

\section{2}

Марголин - Вишняку

Тель-Авив - Нью-Йорк

20 ноября 1951

$20 / 11-<19>51$

Дорогой г. Вишняк,

[нам известно Ваше имя - но не отчество]

Мы с женой сердечно благодарим за оттиск из «Н<ового Журнала» с В<ашей> статьей Израиль [1]. Единственный недостаток статьи - чересчур вежливо. Нашу публику надо матом крыть, а не писать, что «Израиль невелик и необилен, но порядок в нем есть» [2]. Прочтя эти вступительные строки, один мой знакомый до того обиделся, что отказался дальше читать. Но мы всё прочли - с удовольствием. Страна у нас такая, что приезжать и уезжать из нее одинаково приятно. Я это лишний раз проверил, съездив во Францию в сентябре-октябре.

Теперь же очень хочется мне попасть в Соединенные Штаты. Я даже сказал Сиднею Хуку, профессору («New-Leader» etc...) [3], что если бы дали мне стипендию где-нибудь в академ<ическом> центре в провинции - на год - то я бы обязался написать книжечку Man's Freedom, о свободе, не скучно, как все пишут, а с полетом и фейерверком! - Но С. Хук, которого я видел в сентябре в Эльзасе, решил, что я нео-гегельянец: всё равно, как Вы решили, что я «антисоциалист» - и, приехав домой в Н<ью->Йорк, забыл про меня. А здесь, в Т<ель->Авиве, нет книг, источников, и что-нибудь путное писать немыслимо.

Спор об Израиле будем продолжать лично при встрече в Нью-Йорке.

Уважающий Вас,

Ю. Марголин

1. По впечатлениям от своей поездки (см. предыдущее письмо) Вишняк написал статью Израиль, напечатанную в «Новом журнале» (1951, кн. 26, с. 217-236).

2. Статья Вишняка начиналась так:

Израиль - невелик и необилен, но порядок в нем есть. Это первое, что бросается в глаза и поражает особенно сильно, может быть, только рус- 
ского туриста. Кто помнит <19>17-ый год, не может не провести параллели между тем, что стало за один тот «безумный» год с великой, не пространством только, обильной и могучей Россией и что удалось создать на крохотной, запущенной, со всех сторон незащищенной части Палестины. Строить приходилось на пустом месте, часто - из ничего. Уходившая из Палестины английская администрация не только не оставила ничего, что могло бы пойти на пользу ее преемникам, - она умышленно разрушала необходимое для сохранения порядка, подрывала и осложняла возможность образования нового правопорядка. И тем не менее он создался и существует. Это было едва ли не самым трудным. Это, может быть, и самое значительное из многих достижений молодого, насчитывающего всего три года государства (М. Вишняк, Израиль (Из впечатлений), «Новый журнал» 1951, кн. 26, с. 217).

3. Сидней Хук (Sidney Hook, 1902-1989), американский философ, который после перенесенной в молодости «болезни левизны» - увлечения коммунистическими теориями, со временем стал одним из самых беспощадных критиков тоталитаризма, фашизма и марксизма-ленинизма. Автор многочисленных статей, напечатанных в известном американском журнале политики и культуры «The New Leader» (1924-2006).

3

Марголин - Вишняку

Тель-Авив - Нью-Йорк

30 ноября 1952

Тель-Авив, 30/11-<19>52

\section{Дорогой друг,}

Ваш непосредственный отклик по прочтении книги очень обрадовал меня [1]. Я гораздо больше доволен русским изданием, чем франц<узским> переводом [2], но все-таки: из 650 стр<аниц> было напечатано 400, и у меня были серьезные сомнения насчет эффекта этой урезанной, кургузой версии [3]. Я себя чувствовал художником, которому соскребли с картины 40\% красок или отрезали часть полотна под предлогом, что «не умещается в раму». Кестлеру какому-нибудь, небось, не посмеют урезать 250 стр<аниц> из книги [4], а ко мне было отношение, как к поставщику «информаций»: выбрать, что поинтереснее, остальное в корзину. Пропали многие крепкие и для целости нужные страницы. Поэтому Ваша оценка меня очень подбодрила.

Я написал в Изд<ательст>во, прося сообщить мне, что они предпринимают для распространения книги в Израиле, но от- 
вета не имею еще... Понимают ли они, что здесь может быть продана значительная часть их 3.000-ного тиража? Что надо послать экземпляры Бен-Цви (президенту будущему...) [5], Шарету [6], Динабургу (министру просвещения) [7] и прочим русским выходцам, также из «просвещенного лагеря»?.. Месяц спустя выхода книги на моих руках один экземпляр, и вообще ни одной книги Чеховского Изд<ательст>ва здесь в продаже нет и не было... Издалека трудно мне с ними сговориться... Я собирался в ноябре поехать в США, но... в Консульстве объявили мне, что для лиц, подобных мне, родившихся в России и даже сидевших там в тюрьме (imprisonment) - советской тюрьме - формальности, связанные с получением визы, возьмут «от 3 до 9» месяцев... Так что уж не знаю, когда попаду в Нью-Йорк.

Пока пишу книжку под названием Дорога на 3anad [8] и много публицистики. На будущей неделе читаю лекцию (на иврите) Трагедия Русского Еврейства. Все здесь возбуждены процессом Орена в Праге [9]. Ближайшим результатом этого процесса, однако, явится... усиление Изр<аильской> компартии, т.к. многие члены просоветского несчастного МАПАМа (партии Орена), поставленные пред альтернативой - туда или сюда, сионизм или коммунизм - выберут коммунизм [10]. И это хорошо так - под условием, чтобы пр<авительст>во нашло в себе мужество ликвидировать Ком<мунистическую> партию, что, по-моему, было бы единственным логическим следствием из создавшегося положения...

Сердечный привет Вам и Вашей жене от нас обоих.

Ю. Марголин

1. Вероятно, в недошедшем до нас письме Вишняк сообщал свой «непосредственный отклик по прочтении книги» Путешествие в страну Зе-Ка, который он позднее изложил в виде рецензии, напечатанной в «Новом журнале», см. следующее письмо.

2. Т.е. книгой, увидевшей свет в нью-йорском издательстве им. Чехова (1952), нежели французским переводом, который, кстати сказать, вышел в свет раньше русского оригинала: J. Margoline, La condition inhumaine: Cing ans dans les camps de concentration Sovietiques, traduit par N. Berberova et Mina Journot, Calmann-Levi, Paris 1949.

3. Рукопись Путешествия была подвергнута в издательстве Чехова суровой редактуре: треть текста в печатную версию не вошла. 
4. Артур Кестлер (Arthur Kestler, 1905-1983), английский писатель еврейского происхождения, уроженец Венгрии. Марголин прежде всего имеет в виду его роман Слепящая тьма (1940), описывающий годы «большого террора» в СССР.

5. Ицхак Бен-Цви (собств. Шимшелевич, 1884-1963), государственный и общественно-политический деятель, второй президент Государства Израиль (8 декабря 1952 - до конца жизни). Родился на территории Российской империи, в г. Полтава, и владел русским языком, поэтому Марголин пишет о нем как о потенциальном читателе своей книги.

6. Моше Шарет (собств. Шерток [Черток], 1894-1965), государственный и общественно-политический деятель (2-й премьер министр Израиля, 1954-1955), писатель. Родился на территории Российской империи, в г. Пинске, и владел русским языком.

7. Бен-Цион Динур (собств. Динабург; 1884-1973), государственный и общественно-политический деятель, педагог, историк; министр народного образования и культуры (1951-1955 годы). Родился на территории Российской империи, в Полтавской губернии, и владел русским языком.

8. Первые фрагменты из Дороги на Запад были опубликованы в «Новом журнале», см. Галя (1953, кн. 33, с. 107-23), Non omnis moriar (1953, кн. 35, с. 59-71). Много лет спустя после смерти автора, его тексты, включая Дорогу на Запад, появились на сайте https://margolin-ze-ka.tripod.com/commentary09.html благодаря энтузиазму и стараниям проф. Инны Андреевны Добрускиной, занимавшейся описанием и изучением архива Марголина в Central Zionist Archives (Jerusalem). С неполной версией книги познакомил читателей «Иерусалимский журнал» (2007, № 24); текст Дороги на Запад опубликован в кн. Ю. Марголин, Путешествие в страну зека, в 2-х книгах, кн. 2, Институт Жаботинского в Израиле, Тель-Авив 2017, с. 224-313.

9. Родившийся в галицийском городке Подгайцах, Мордехай Орен (1905-1985) был одним из основателей молодежного сионистского движения Хашомер Хацаир. Репатриировался в Эрец-Исраэль в 1929 г. Был среди создателей партии МАПАМ (Hamiflaga hapoalim hameuhedet - Объединённая рабочая партия). Его леворадикальные взгляды отразились в написанной им брошюре Jews, Arabs and British in Palestine: A Left Socialist View, Kibutz Artzi Hashomer Hatzair, London 1936. В годы «холодной войны» занимал просоветскую идеологическую позицию. Возвращаясь в ноябре 1951 г. в Израиль из Восточного Берлина, где он представлял в качестве наблюдателя партию 
МАПАМ во Всемирной федерации профсоюзов и на конференции по вопросам компенсации восточногерманским жертвам Холокоста, Орен вместе с сопровождавшим его Шимоном Орнштейном был задержан в Праге. Причем сам факт их ареста был скрыт и от родственников, и от израильской и мировой общественности, и только через полгода, в конце марта 1952 г., власти Чехословакии объявили о том, что они оба подозреваются в нарушении государственной безопасности. На устроенном показательном суде из уст Орена прозвучали признания в том, что он якобы занимался шпионской деятельностью против стран народной демократии - Польши, Венгрии, Чехословакии, Болгарии, Румынии и Восточной Германии, в пользу британской разведки, - признания эти были выбиты из него под жестокими пытками (кроме того, ему угрожала транспортировка в Москву в качестве подставного свидетеля на процессе по «делу врачей»). В результате судебного разбирательства он был приговорен к 15-ти годам лишения свободы (впоследствии, в Связи со смертью Сталина, срок был значительно сокращен, и сам он освобожден; в 1963 г., в «оттепельные времена», дело было пересмотрено, и Орен полностью оправдан).

Марголин обращался к этому историческому сюжету в своих статьях несколько раз - и в подробной форме, как в статье История одного несчастья («Новое русское слово» 1958, № 16332, 16 марта, с. 2, 7), и в форме исторических аллюзий, описывая, например, в Уроках прошлого, как «заплечных дел мастера в Праге» избрали в качестве своей жертвы одного из самых «воинствующих и злобных сталинистов в Израиле» («Новое русское слово» 1963, № 18277, 25 марта, с. 2).

10. Действительность полностью подтвердила пророчество Марголина: Орен, несмотря на «Пражский процесс» - лживые обвинения, пытки и унижение, которым он подвергся со стороны репрессивной коммунистической машины, остался верен своему политическому credo, изложенному в книге, написанной на иврите, - Rshimat asir Prag [Notes of a Prague Prison] (1958).

4

Марголин - Вишняку

Тель-Авив - Нью-Йорк

8 апреля 1953 [1]

Тель-Авив, 8 апреля $<19>53$

Шенкин, 16 
Прежде всего надо поблагодарить Вас за рецензию в «Н<овом> Журнале» [2]. Она лишь недавно дошла до меня. Здесь книга идет довольно хорошо, и думаю, что при условии хорошей рекламы, объявлений и рецензий, продастся в течение года до 1500 экз<емпляров>. А лучше всего идет, конечно, Зощенко [3]. Имею предложение от солидного изд<ательст>ва издать книгу на иврите, но... не могу найти переводчика. На беду все хорошие переводчики - сталинцы [4].

Засим извещаю Вас, что в середине мая приблизительно явлюсь в Нью-Йорк [5]. Пароходом Иерушалаим прямо из Хайфы. Это мой первый приезд в Америку. Тогда и повидаемся. Хотелось бы мне вот что сделать: написать сценарий для фильма Страна Зе-Ка и убедить какого-нибудь Дарриля Занука [6], что страна эта не менее интересна, чем Ява и Бали, и стоит выстроить в Холливуде на 2 гектарах копию советского лагеря, без мистификации, точнехонько, нанять тысячу статистов и закатить фильм, который не до тысяч дойдет, как книга, а до миллионов... Какое Ваше мнение? Теперь, конечно, в воздухе розовая пыль, большие надежды, НИП (Новая Иностр<анная> Политика) - но 1) воробья на мякине не проведешь, а во-2), ясно, что наше дело нажимать, не давать успокоиться, продолжать бескомпромиссную борьбу против существующего зла. Но неужели еще не пробовали отразить лагеря на экране?

До скорого свидания

Привет В<ашей> супруге [7].

Ю. Марголин

\section{1. Отпечатано на машинке.}

2. Речь идет о рецензии Вишняка на книгу Марголина Путешествие в страну Зе-Ка, которая появилась в 31-й книжке «Нового журнала» за 1952 г., с. 320-22 и начиналась следующими словами:

Это мужественная и замечательная книга. И написана она превосходно, местами - художественно. По содержанию же она потрясающа. Я полностью отдаю себе отчет в смысле этого слова (с. 320).

Главное «потрясение» книги Марголина рецензент испытал от того, с какой легкостью в тоталитарном обществе может быть растоптана человеческая личность, расчеловечена, превращена в раба, в «гужевой или иной скот», в «лагерную пыль». Путешествие, - говорилось в рецензии, - 
останется, как вечный памятник умученным жертвам и неопровержимое свидетельство против человекообразных преобразователей природы человека и общества (с. 322).

3. Имеется в виду: М. Зощенко, Повести и рассказы, Изд-во им. Чехова, Нью-Йорк 1952.

4. Книга Путешествие в страну Зе-Ка была переведена на иврит через много лет после смерти автора, см. Masa le-aretz haasirim (Karmel, Jerusalem 2013), переводчик — Idit Shaked.

5. В этот свой приезд в Америку Марголин, среди других дел, 22 мая читал доклад в нью-йорском обществе Надежда, который, по словам освещавшего его в «Новом русском слове» Григория Аронсона (репортаж подписан инициалами Г.А.),

привлек многолюдную аудиторию, охваченную единым настроением: желанием не только услышать непосредственно из уст автора прославленной книги Путешествие в страну зе-ка о том, что он испытал в стране советов в тяжкую полосу своей пятилетней каторги в концентрационных лагерях, - но и почтить его. Это настроение выразилось в тех дружных аплодисментах, которые покрыли краткое слово председательствовавшего В.М. Зензинова, обращенное к Ю.Б. Марголину, и которыми аудитория приветствовала самого лектора.

\section{На вечере, сообщалось далее, израильский гость}

предложил вниманию аудитории два своих произведения, из которых одно представляет главу, не вошедшую в книгу его Путешествия - Иван Александрович Кузнецов ${ }^{6}$, а другое - рассказ Галя, который появится в ближайшей - 33-ей книге "Нового журнала» (Г.А., На вечере Ю.Б. Марголина, «Новое русское слово» 1953, № 15005, 27 мая, с. 3).

6. Дэррил Фрэнсис Занук (Darryl Francis Zanuck, 1902-1979), американский кинопродюсер, сценарист, актер и режиссер.

7. Мария Абрамовна Вишняк (урожд. Вишняк, ум. 1955), жена Вишняка (с 31 августа 1908) и одновременно его кузина.

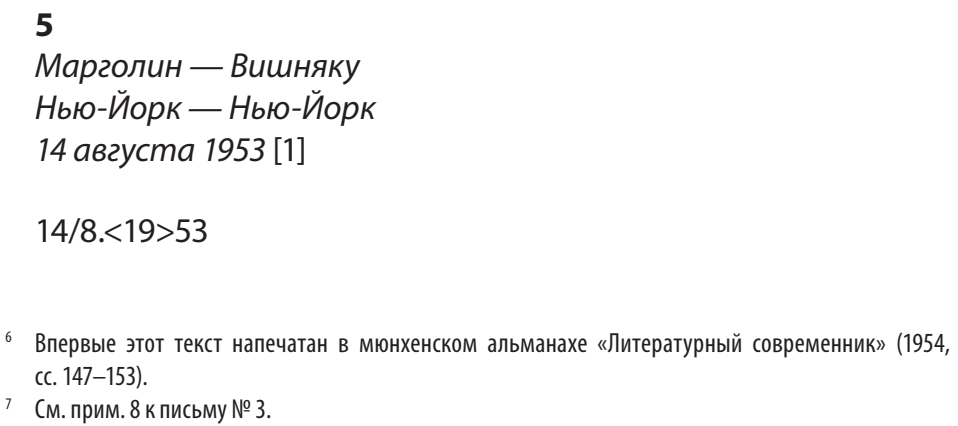




\section{Дорогие друзья}

Марк Вениаминович и Мария Абрамовна!

К сожалению, по возвращении из Мексики мне не удалось связаться с вами. Ваш телефон был disconnected. Я еще успел 5 авг <уста> съездить на ферму РОВА, где читал о Сущности коммунизма [2] и дал согласие "Commentary» напечатать экстракт из моего доклада о русском еврействе с «ретушью», т.е. чтобы сгладить его «черезмерный» сионизм [3].

Уезжаю завтра, 15-го, через 10 дней буду дома (Shenkin 16, T<el> Aviv) [4]. Эта открытка - вместо личного прощания с вами.

Не забывайте меня и при случае дайте знать о себе.

До свидания (когда?)

Ю. Марголин

1. Написано на почтовой карточке.

2. Ферма РОВА (РООВА) - Русское объединенное общество взаимопомощи в Америке, возникла в 1890 г. на основе иммигрантов из Австро-Венгерской империи, которые присоединись к иммигрантам из России, прибывшим в Америку до Первой мировой войны. В 1934 РОВА приобрело землю в штате Нью-Джерси, на которой возник русский поселок, названный «Фарма РОВА» («Ферма РОВА»), который и посетил Марголин и где прочел упоминаемую в письме лекцию.

3. Речь идет о статье Марголина Do We Leave the Russian Jews to Their Fate? (The Face Extinction, Unless), напечатанной в американо-еврейском журнале «Commentary» (1953, vol. 16, n 4, October, c. 321-27).

4. В бумагах Марголина сохранилось письмо, написанное им по приезде в Израиль и адресованное Ицхаку Рабиновичу (1887-1971), одному из активных участников сионистского движения в России, и дореволюционной и советской, который после высылки в Эрец-Исраэль в 1929 г. много лет возглавлял русский отдел Еврейского агентства Сохнут (1933-1953) и являлся председателем Союза выходцев из СССР. Некоторые детали из этого письма перекликаются с тем, о чем говорится в его письме Вишняку (Central Zionist Archives, A386/9; A536/52):

Многоуважаемый г. И. Рабинович,

Несколько дней тому назад я вернулся из 4-хмесячного путешествия по Америке, и мне передали, что Вы предпринимаете шаги по организации 
Комитета Русских евреев, "yotzey rusia» ${ }^{8}$. Этот вопрос живо интересует меня, так же как и создание органа Русских Евреев в Израиле. Это ведь моя старая мысль. В Нью-Йорке (22 июня) я читал доклад в Союзе Рус<ских> Евреев о Трагедии Русского Еврейства. Статья на эту тему мною передана в нью-йоркский «Commentary». Я выступал также и в Париже, в тамошнем Союзе Русских Евреев. Есть у меня контакты и связи заграницей. Вы знаете меня, как автора книги Путешествие в страну Зе-Ка. Короче, я прошу Вас держать меня в курсе предпринимаемых Вами шагов и привлечь меня к участию в организационной группе, если есть такая. Я думаю, что смогу помочь. Напишите мне или протелефонируйте по № 6-2398 в Тель-Авиве.

С уважением

Ю. Марголин

\section{6}

Марголин - Вишняку

Тель-Авив - Нью-Йорк

17 ноября 1957

$17 / 11-<19>57$

\section{Дорогой Марк Вениаминович, -}

Посылаю Вам страницу из а' ה с с заметкой о Вашей книге [1]. Не знаю, читаете ли на иврите [2], но на всякий случай обращаю $\mathrm{B}<\mathrm{aше>} \mathrm{внимание} \mathrm{на} \mathrm{рецензию} \mathrm{о} \mathrm{5-й} \mathrm{книге} \mathrm{лу} \mathrm{(Прошлое)}$ - это журнал вроде «Еврейской Старины» [3], и там посмертная статья Ксении, Воспоминания о трех революционерках: Рахили Лурье, Доре Бриллиант и Эстер Лапиной [4].

Вы меня порицаете за вторичное мое появление на конференции [5], созванной Посевом [6]. А вот мои контрдоводы:

1) Я не русский эмигрант, никого, кроме собственной персоны, не представляю и чувствую себя свободным принимать приглашения на любую интересующую меня конференцию, где хотят меня видеть в качестве гостя и наблюдателя.

2) Конференция дает мне единственную возможность повидать друзей из разных стран (Ги де Винатрель, Сюзанна Лабэн из Парижа, Ноэми Эскюль-Йенсен из Копенгагена [7] и лично мне симпатичная Н. Тарасова из «Граней» [8]).

3) Есть решающий аспект, о котором Вы забываете, а я не могу распространяться: сионизм революционный (или контрреволюционный, как хотите) заинтересован в осторожном разведывании путей и контактов с «той стороной». Мы достаточно осторожны, но не боимся разговаривать и с «подозрительными» и с подозреваемыми во всех грехах.

\footnotetext{
8 Выходцев из России (в подлиннике на иврите).
} 
4) Что касается антисемитизма (укрываемого) этих людей, то я предпочитаю антисемитов, издающих мои книги, Чех<овскому> изд<ательст>ву, не захотевшему издать продолжения моего Путешествия в страну Зе-Ка [9]. Грани печатают мою работу О свободе (1951 г.) [10] Вспоминаю, что другой мой очерк, О лжи, начали, было, печатать Опыты в Нью-Йорке и бросили... [11] Был неприязненный отзыв Гр. Аронсона, не понявшего, что пред ним первые страницы большой работы и надо погодить выносить отрицательное суждение [12]. Что же удивительного, что я иду туда, где меня хотят печатать? Изд<ательст>во Посев предлагает мне издать мою Еврейскую повесть (биографию И. Эпштейна, члена Иргун Цваи Леуми, убитого в Риме в 1946 г.) [13]. Какой Вы мне дадите совет - отказаться?

5) Затем атмосфера съезда и вокруг него была исключительно приятной. Я не выступал там с речами (говорили двое других из Израиля, мои друзья, Кабири [14] и д-р Шехтер с 8-летним стажем в Воркуте [15]), но на вечере-встрече в доме Н. Тарасовой прочел реферат о «современном иврите». Другой вечер был посвящен воспоминаниям С.К. Маковского о Гумилеве и Ахматовой [16]. А на обратном пути в Париже я познакомился с Борисом Зайцевым, которого с молодости читаю и чту [17]. Ну что же плохого, что я поехал во Франкфурт? - Пригласите меня в Нью-Йорк, я тоже приеду.

С сердечным приветом -

Ю. Марголин

1. Речь идет об отзыве на книгу Вишняка Дань прошлому (Изд-во им. Чехова, Нью-Йорк 1954), написанном самим Марголиным (Mas le-avar [Дань прошлому]) и опубликованном в израильской газете «Haboker» (1957, n 6682, November 8, p. 6).

2. Вишняк иврита не знал. Когда поднялся вопрос о его переселении в Эрец-Исраэль, о чем говорилось выше, одной из главных проблем, вставшей перед ним, человеком уже немолодым, достигшим 50-летнего возраста, стало изучение древнееврейского языка.

3. Ср. в рецензии Марголина («Прошлое» о прошлом) на 10-ю книжку этого журнала (1962), подписанную его псевдонимом А. Галин, которая начинается примерно той же фразой («Вестник Израиля» 1962, № 36, ноябрь-декабрь, с. 33):

Трехмесячный журнал, посвященный истории русских евреев, тельавивский «ге-Авар» (Прошлое), продолжает традицию «Еврейской старины», выходившей в Петербурге в годы Первой мировой войны, и одноименных сборников на иврите, выходивших там же в 1917-1918 гг. 
4. Имеется в виду мемуарный очерк Ксении ПамфиловойЗильберберг о перечисленных Марголиным трех русских революционерках, которых автор хорошо знал в годы своей жизни в России, см. Xenia, Shalosh mehaphaniyot yehudiyot [Три еврейки-революционерки], Heavar (Tel Aviv) 1957, vol. 5, pp. 104-15 (Hebrew). Ксения Ксенофонтовна ПамфиловаЗильберберг (партийная кличка «Ирина», 1881-1957), русская революционерка, член боевой эсеровской организации. После того, как царская охранка раскрыла террористическую группу, членом которой она являлась, и начались повальные аресты (среди других был арестован и затем казнен муж Ксении - Лев Зильберберг), она с их малолетним ребенком, тоже Ксенией, сумела бежать из России, куда никогда более не возвращалась. В 1931 г. ее бывшие «товарищи по оружию», жившие в Эрец-Исраэль и ставшие там значительными фигурами - Моше Бейлинсон и Пинхас Рутенберг (см. упоминание о нем выше), помогли ей, русской по крови и христианке по вере, обрести второе отечество в этой стране: Ксения Ксенофонтовна поселилась в кибуце Наан, где прожила до самой смерти. Там ее навещал Марголин, написавший о ней очерк, см. Ю. Марголин, В гостях у Ксении, «Новое русское слово» 1955, № 15765, 26 июня, с. 3. См. о ней также: О. Дымов, Вспомнилось, захотелось рассказать... Из мемуарного и эпистолярного наследия, в 2-х томах, т. 2: В дружеском и творческом кругу Дымова (сост. и коммент. В. Хазана), The Hebrew University of Jerusalem, Jerusalem 2011, с. 144-50; В. Хазан, Пинхас Рутенберг: Om террориста к сионисту: Опыт идентификации человека, который делал историю, в 2-х томах, Гешарим-Мосты культуры, Иерусалим-Москва 2008 (по индексу имен); Heavy Burden of Responsibility for the Country, part 1: Russian Political Émigrés and Eretz Israel (edited by V. Khazan), The Hebrew University of Jerusalem, Jerusalem 2020 (Eretz Israel and the Russian Émigrés in Europe: Contacts, Connections, Communications, Interactions (1919-1939), vol. II) - по индексу имен; В. Хазан, Мать Мария: израильские отзвуки трагической судьбы // Unacknowledged Legislators: Studies in Russian Literary History and Poetics in Honor of Michael Wachtel, (ed. by L. Fleishman <et al.>), Peter Lang, Stanford 2020 (Stanford Slavic Studies, vol. 50), с. 897-978.

5. Судя по всему, имеется в виду Конгресс за права и свободу в России, состоявшийся 25-27 апреля 1957 г. в Гааге, см. сборник его материалов, изданных в том же году в PossevVerlag. 
Как можно думать, в недошедшем до нас письме Вишняка содержалась резкая критика в адрес Марголина, принявшего участие в этом Конгрессе, объединившем не только антикоммунистические силы, с которыми Вишняк, безусловно, солидаризировался, но также радикально-патриотические белоэмигрантскиеорганизацииантисоциалистическогоидажемонархического толка, как, например, Российское Национальное Объединение, основанное в Бельгии 27 июля 1947 г., чья идеологиявзначительноймереосновываласьнамахровомюдофобстве.

6. Антикоммунистическое издательство Посев, издававшее помимо книг, журнал под одноименным названием (1945-1992, далее издавался в России), а также журнал «Грани» (1946-1990, далее издавался в России), было основано в 1945 г. в лагере для перемещенных лиц Менхенгоф; в 1947 г. оно переехало в Лимбург-на-Лане, а в январе 1952 г. обосновалось во Франкфурте-на-Майне.

7. Марголин перечисляет западных писателей, журналистов и политологов, своих знакомых и друзей, так же, как и он, боровшихся печатным словом с тоталитаризмом: французов Ги Винатреля (Guy Vinatrel, 1915-1980), Сюзанну Лабен (Suzanne Labin, 1913-2001) и датчанку швейцарского происхождения Ноэми Эскюль-Йенсен (Noemi Eskul-Jensen, 1901-?).

8. Наталья Борисовна Тарасова (урожд. Жук, 1921-2006) была многолетним редактором (1962-1982) журнала «Грани» (с 1954 г. работала в издательстве Посев; в 1954-1955 г. - секретарь редакции «Граней»; в 1955-1961 г. - заместитель редактора). Приняла монашеский обет и последние годы жизни провела в монастыре во Франции под именем матери Александры. После выхода в свет 1-й книжки нью-йорского альманаха «Воздушные пути» (1960), в котором Марголин был представлен своим философским эссе О Боге великом (с. 259-82), она в письме от 15 ноября 1960 г. писала его редактору и издателю Роману Гринбергу:

Альманах Ваш очень хорош. Я с удовольствием его просмотрела. Пришлось отдать рецензенту (у нас такое правило), а хотелось бы иметь. Если у Вас есть еще возможность достать и прислать мне один экз<емпляр> наложенным платежом, я была бы Вам очень признательна. Интересно в нем все. Увидела я там своего дорогого друга Юлия Борисовича Марголина. У нас в «Гранях» он когда-то печатал интереснейшую философскую работу о свободе, которую писал в первый раз в концлагере в России, при выходе у него отобрали и, разорвав, бросили в корзинку, даже не поинтересовавшись содержанием. Вырвавшись на Запад, он повторил ее, а мы опубликовали (Library of Congress (Washington). Manuscript Division. The Records of Vozdushnye puti. Box 3). 
См. далее прим. 10.

9. См. прим. 3 к письму № 3.

10. Речь идет о философском трактате О свободе, напечатанном с продолжением в двух книжках журнала «Грани» за 1957 г. (№ 34/35, апрель-сентябрь, с. 305-35; № 36, октябрь-декабрь, c. 211-23). Как и упоминаемый им следом текст О лжи (и еще один - Учение о ненависти) первоначально были созданы еще во время пребывания Марголина в советском концлагере и, найденные у него при обыске, уничтожены. В книге Путешествие в страну Зе-Ка он так описывал эту варварскую экзекуцию, которой подверглись его рукописи:

Мне не полагалось иметь при себе никаких бумаг. Никто не интересовался их содержанием. При мне все выбросили в грязь, в кучу мусора. Я, голый, стоял рядом и смотрел, как исчезли 3 года моей мысли и труда не советского нормированного труда, а того, который родится однажды, без позволения и без предупреждения, в одиночестве, - и так же неповторим, как жизнь, породившая его.

Пропала книга! - и никогда уже ни мною, ни кем-либо другим она не будет написана так, как создавалась в те годы, когда не было под рукой ни библиотек, ни самых элементарных удобств, когда каждая строка добывалась с бою и была вызовом судьбе. Пропала книга, писанная в лагере, в страхе, с оглядкой и с соблюдением всех предосторожностей, которую годами надо было укрывать от обысков и шпионов. Пропал трагический и странный парадокс - книга о лжи, писанная среди лжи, книга о ненависти, писанная среди ненависти, - книга о свободе, писанная в заключении. В продолжение лет я, как ребенка, носил ее с собой, - и она росла с годами мучений, пока плоть моя убывала, точно вся моя жизнь переходила в нее. 28 глав Учения о Сободе были, наверное, единственным в истории литературы документом, где рациональный анализ неразличимо сливался с безумием, а жизнь со смертью, стоявшей неотступно за плечами. Никогда не повторятся для меня годы, проведенные в мрачном плену, и никогда я не буду в состоянии ни восстановить хода той мысли, ни отделить ее от условий, в которых она родилась. Другие времена, другие песни!.. Пропала книга! Ясно, нельзя писать книг в лагерях. Но разве это единственная книга, которая пропала в мире? Над могилой миллионов, над свежим пепелищем, над океаном человеческой крови и злодеяний за нами, вокруг нас и в будущем - разве место и время вспоминать об одной единственной книге?.. (Ю. Марголин, Путешествие в страну Зе-Ка, в 2-х книгах, кн. 2, Институт Жаботинского в Израиле, Тель-Авив 2017, с. 173).

Cр. в письме, написанном по другому поводу, Le-yadidei Israelik (см. прим. 6 к письму № 10), Марголин вспоминал о том, как он

стоял голый во дворе вологодской тюрьмы при обыске на этапе из одного советского концлагеря в другой. Руки работников НКВД вытряхнули мои пожитки и нашли мой самый скрытый секрет: черновик книги, которую я несколько лет писал втайне в лагере - книгу О свободе. Запрещено писать в лагере книги о свободе. И рукопись уничтожили у меня на глазах. Они даже не потрудились прочитать ее. 
И в заключении этого пассажа он иронически вопрошал: «Может, если бы прочли, не уничтожили бы?»9.

11. Имеется в виду философское эссе Марголина О лжи, которое, после того, как в годы его заключения в советских лагерях был уничтожен первый вариант, он написал вновь и которое было напечатано двумя небольшими порциями в нью-йорском журнале «Опыты» (1953, кн. 2, с. 88-99; 1957, кн. 8, с. 118-25).

12. Марголин ссылается на рецензионную статью литературного обозревателя «Нового русского слова» Григория Аронсона, который в отзыве на 2-ю книгу «Опытов» писал буквально следующее:

Размышления Ю. Марголина О лжи, - начальные главы «опыта», как называет редакция журнала его статью, - могли бы сильно выиграть, если бы были введены в русло существующей довольно большой литературы о психологии лжи (и на русском языке) - о судебной лжи, о лжи у детей и т.д. Автор открывает уже давно открытую Америку и впадает поэтому порой в тривиальность (Г. Аронсон, «Опыты», книга вторая, «Новое русское слово» 1953, № 15177, 15 ноября, с. 8).

Любопытный отзыв на марголинские размышления о лжи оставил поэт Владимир Злобин, литературный секретарь Дмитрия Мережковского и Зинаиды Гиппиус, который, обозревая журнал «Опыты», отмечал:

\footnotetext{
Что до статьи Ю. Марголина О лжи, то она интересна и значительна, но отнюдь не как задуманный автором философский трактат, серьезной критики, кстати, не выдерживающий, а со стороны чисто эмоциональной. Важна та сила, с какой Марголин отрицает ложь во всех ее проявлениях. Это почти физиологическое отвращение ко лжи важнее всяких о ней умствований и никакого философского обоснования не требует. Размышлять о лжи, конечно, никому не возбраняется, как вообще не возбраняется размышлять о чем угодно. Но Марголин не прав, утверждая, что до сих пор о лжи мало думали и мало говорили и что философски обоснованную теорию представить себе нельзя. Напротив, одна из заслуг - и не малая - современной философский мысли в том, что она методологически правильно и религиозно праведно трактовать вопрос о лжи как проблему автономную отказалась, включив ее в общемировую проблему зла. Не ложь, а зло, «как океан объемлет шар земной». Но непримиримая борьба автора Путешествия в страну Зека с ложью, этой самой ужасной формой зла, свидетельствует о его исключительной душевной чистоте и неподкупной совести, явлениях в наши дни редчайших, пренебрегать которыми было бы непростительной ошибкой (В.А. Злобин, Тяжелая душа: Литературный дневник, воспоминания, статьи, стихотворения (ред. Л.М. Суриса), Директ-Медиа, Москва-Берлин 2016, с. 89).
}

13. В конце концов, Еврейская повесть была издана в Израиле, см. Ю. Марголин, Еврейская повесть, Мааян, Тель-Авив 1960.

9 Перевод с иврита Миши Шаули. 


\title{
14. Сведений об этом лице обнаружить не удалось.
}

15. Речь идет об израильском адвокате И. Шехтере, бывшем узнике ГУЛАГа, одном их тех, кто вместе с Марголиным подписал в 1954 г. Прокламацию бывших узников советских конилагерей:

БЫВШИМ УЗНИКАМ СОВЕТСКИХ ЛАГЕРЕЙ, ГРАЖДАНАМ ГОСУДАРСТВА ИЗРАИЛЬ

Союз выходцев из советских исправительно-трудовых лагерей, включающий в себя граждан Израиля без различия партий, политических и социальных взглядов - ставит перед собой следующие цели:

Не дать забыть о миллионах заключенных в советских лагерях, среди которых сотни тысяч евреев и десятки тысяч сионистов.

Требовать помощи общества в моральной и материальной поддержке евреям, находящимся в советском аду.

Требовать общественной помощи тем, кто сумел вырваться из советских лагерей, тем, кто нуждается в физической, моральной и материальной помощи.

Но прежде всего Союз обращается к тем, кто прошел путь страданий и мучений, путь пыток, к тем, кто на своей шкуре испытал удары советского кнута:

на угольных шахтах Караганды и Воркуты,

на Архангельских и Карело-Финских лесоповалах,

на золотых приисках Колымы

и в других лагерях рабского труда, в которых содержались и содержатся евреи;

из-за их отказа принять советское гражданство;

из-за того, что они сионисты и евреи;

из-за того, что это люди со своим собственным мнением,

непорабощенным тоталитарной инквизицией.

Мы не забыли и никогда не сможем забыть ад, из которого спаслись! Не дадим забыть других, наших братьев по страданию. На нас лежит святая обязанность выполнить обещание, которое давал каждый из нас, покидая лагерь, тем, кто оставался там. И мы обещали, все мы клятвенно обещали сделать это для миллионов рабов - привлечь весь свободный мир к делу их спасения.

Братья по страданию, будем искать пути спасения евреев, находящихся в лагерях; объединимся, чтобы помочь тем, кто вернулся и возвращается с кладбищ, где они были похоронены заживо, из советских закрытых лагерей - лагерей духовного, телесного и физического расчеловечения.

Братья по страданию, потребуем публично, чтобы режим, ответственный за удержание рабов, выплатил компенсации за годы рабства тем, которые в течение долгого времени подвергались там духовному унижению.

Брат по страданию и мучениям, Выполни свой долг и присоединись к нашему Союзу.

Прием членов и запись каждое воскресение и четверг, с 9 до 6 часов вечера в секретариате Общества: ул. Шенкин,16, Тель-Авив

\author{
Члены временной комиссии: \\ доктор Ю.Марголин \\ адвокат И. Шехтер \\ адвокат И. Минц \\ адвокат Ш. Киршенберг \\ Моше Гроссман, писатель
}


16. Поэт, литературный и художественный критик, редактор, издатель, мемуарист Сергей Константинович Маковский (1877-1962) был, по выражению современника, «настоящим 'осколком' [...] блистательного чиновного Петербурга» (И.В. Чиннов, Собрание сочинений, в 2-х томах, т. 2 (сост., подг. текста, коммент. О. Кузнецовой, А. Богословского), Согласие, Москва 2002, с. 141). Сын известного живописца Константина Егоровича Маковского (1839-1915) и петербургской красавицы Юлии Павловны Летковой (1859-1954), он, «один из двигателей и патронов русского искусства, замечательный знаток живописи и других художественных ценностей» (А.В. Амфитеатров, «Жили-были три сестры» (Памяти Ек.П. Летковой), «Сегодня» 1937, № 167, 20 июня, с. 4), принадлежал к культурной элите Серебряного века, о чем оставил две книги воспоминаний: Портреты современников (Изд-во им. Чехова, НьюЙорк 1955) и На Парнасе 'Серебряного века' (ЦОПЭ, Мюнхен 1962) $)^{10}$.

17. Борис Константинович Зайцев (1881-1972), писатель, переводчик, один из последних представителей русской литературной классики.

7

Марголин - Вишняку

Тель-Авив - Нью-Йорк

18 мая 1960

18 мая <19>60

Дорогой Марк Вениаминович,

В связи с Вашим письмом, где вспоминаете, что слышали Жаботинского в Париже в 30-ые гг. [1] - я разговаривал с Паамони из Института им. Жаботинского в Тель-Авиве [2]. Там имеется архив из десятков записанных на пленку рассказоввоспоминаний о Ж<аботинском> людей, его знавших, - и они были бы заинтересованы закрепить и Ваше свидетельство. Воспоминания не обязательно должны быть воспоминаниями «друга», довольно, если будут содержать материал, интересно рассказанный. Если есть у Вас охота - напишите прежде всего мне. Я к 20-летию со дня смерти Жаб<отинского> (в августе) собираюсь вытащить мою ненапечатанную статью о Пя-

\footnotetext{
10 Замысел третьей книги, в которую должны были войти очерки о Николае Гумилеве («Новый журнал» 1964, кн. 77, с. 157-89), Михаиле Кузмине, Владиславе Ходасевиче, Мстиславе Добужинском, остался невоплощенным.
} 
mерых <sіс> Жаб<отинского> [3] и, м<ожет> б<ыть>, пошлю в «Н<овое $>$ Р<усское $>$ Слово» [4].

С Р. Гулем мы дружны, но не переписываемся [5]. Он о рецензии меня не просил, но я в свое время промолчал Скифа в Евpone [6], Азефа хотел отметить [7]. Заметка написана не столько «о», как «около» и «по поводу», а главное в ней - предположение, что Бурцев оказал медвежью услугу, устранив из партии единственного мерзавца, который мог бы быть на уровне грядущих событий [8].

Гуль не реагировал на статью об Азефе, из чего заключаю, что она ему не понравилась [9].

На днях навестила нас Б.М. Авксентьева [10]. Приехала на месяц, живет в Р<амат-> Гане и впервые знакомится со страной.

Мы все под впечатлением срыва конференции в Париже, американской ослиной глупости и хрущевского хулиганства [11].

Одна надежда, да и то слабая, - на нового демократического президента [12]. Кого выберут?

Пишите, дорогой. Моя История евреев где-то застряла в высших сферах [13], а пока в наборе Еврейская повесть [14], которая, боюсь, ни Вам, ни кому другому не понравится [15]. Выйдет осенью.

$\mathrm{E}<$ ва $>\mathrm{E}<$ фимовна > приветствует [16].

Ю.М<арголин>

1. Владимир (Зеэв) Евгеньевич Жаботинский (1880-1940), крупнейший лидер международного сионистского движения, писатель, поэт, переводчик, публицист.

2. Йосеф Паамони (Joseph Pa'amoni, собств. Глукман, 19021966), врач-бактериолог, общественный деятель, один из организаторов медицинской системы в Палестине и Израиле; представитель ревизионистского крыла в сионизме, ему принадлежит инициатива создания Института Жаботинского в Тель-Авиве, первым директором которого он стал.

3. Имеется в виду повесть Владимира Жаботинского Пятеро (отд. изд. 1936).

4. 20-летие со дня смерти Жаботинского в «Новом русском слове» отмечено не было. Марголин посвятил повести Жаботинского статью Распад (1960), которая была включена в его посмертный сборник Четыре статьи (МАОЗ [Общество борьбы за освобождение евреев из СССР], Тель-Авив 1971, c. 22-36).

5. Роман Борисович Гуль (1896-1986), писатель, публицист, историк, редактор «Нового журнала». Марголин познакомился с ним в 20-е гг., живя в Берлине; сохранилась обильная пе- 
реписка между ними, которая в настоящее время готовится к печати.

6. Имеется в виду роман Гуля Скиф в Европе: Бакунин и Николай I (1958), представляющий собой переработанную версию его более раннего романа Скиф (1931); в дальнейшем автор переработал его еще раз, и в 3-м издании он получил название Бакунин (1974).

7. Речь идет о романе Гуля Азеф (1959), который в качестве предшественника имел его же роман Генерал БО (1929).

8. Владимир Львович Бурцев (1862-1942), публицист, снискавший известность как разоблачитель секретных сотрудников российской полиции, в частности, Евно Фишелевича Азефа.

9. Судьба рецензии Марголина на роман Гуля Азеф неизвестна.

10. Берта Михайловна Авксентьева (урожд. Маркушевич,1894-1970), общественный деятель, вторая жена известного русского революционера, одного из лидеров эсеровской партии Николая Дмитриевича Авксентьева.

11. В мае 1960 г. в Париже должна была состояться встреча американского президента Дуайта Эйзенхауэра с советским премьером Никитой Хрущевым, по существу, первый саммит лидеров США и СССР после окончания Второй мировой войны; она была отложена из-за того, что 1 мая 1960 г. над советской территорией был сбит американский самолет-шпион У-2, пилотируемый Гарри Пауэрсом.

12. Т.е. на Джона Фицджералда Кеннеди (John Fitzgerald Kennedy, 1917-1963).

13. Под Историей евреев, вероятно, имеется в виду текст, изданный после смерти Марголина: Повесть тысячелетий: сжатый очерк истории еврейского народа, О-во увековечивания памяти д-ра Юлия Борисовича Марголина, Тель-Авив 1973.

14. См. прим. 13 к предыдущему письму.

15. Марголин оказался прав: его Еврейская повесть многим пришлась не по душе. Упоминавшийся выше Григорий Аронсон (см. прим. 12 к предыдущему письму), например, писал:

Мне думается, что, выступая сейчас в качестве апологета террористических методов иргунистов ${ }^{11}$, автор книги Еврейская Повесть только подчеркивает свою изоляцию в современном Израиле и современном сионизме, который, как известно, не шел за ревизионизмом Жаботинского и деятельностью Иргуна («Новый журнал» 1961, кн. 66, с. 285).

11 Иргунисты - члены боевой подпольной организации Иргун (Иргун Цваи Леуми, сокращенно: ЭЦЕЛ — «Национальная военная организация»); зачастую называлась просто «Иргун» «0рганизация». 
Об отношении к этой книге Вишняка см. в его письме к Марголину, публикуемом в следующем выпуске журнала (№ 9, от 30 ноября 1960).

16. Жена Марголина, доктор философии, издательница детской книги Ева Ефимовна Спектор (1898-1977); см. стихотворение Быть женщиной - и знать, что сердиа стук, посвященное ей поэтессой Татидой (собств. Татьяна Давидовна Цемах, 1890-1943?), жившей в первой половине 20-х гг. в Берлине и затем вернувшейся в советскую Россию (Татида, Восьмистишия, Берлин 1924, с. 21):

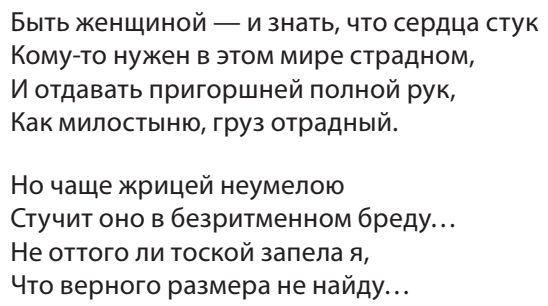

\section{8}

$$
\text { Марголин - Вишняку }
$$

Тель-Авив - Париж

8 сентября 1960

\section{IX. $<19>60$}

\section{Дорогой Марк Вениаминович,}

Спасибо за привет из Парижа. Сегодня я, кроме того, получил ответ от Шазара [1] на мое обращение к нему [2]. Он ответил немедленно, и в своей выспренней манере («Иши га-наале» - обращается ко мне, что значит буквально «mein erhabener Mann!» [3]), очень уважительно и обещая свое содействие. Он уже выяснил, что рукопись передана в «комиссию экспертов», которые всё ее читают - уже год читают! Авось теперь, с помощью Шазара, наконец дочитают. Я не уверен, что это письмо Вас застанет в Париже, но отвечаю сразу. Передайте мой привет и $\mathrm{M<арии} \mathrm{>} \mathrm{Самойловне} \mathrm{[4],} \mathrm{и} \mathrm{Водову} \mathrm{[5].} \mathrm{Я} \mathrm{ему} \mathrm{сегодня}$ выслал две статейки сразу. Жарища у нас по-прежнему 30 plus. Так что я охотно условился бы с Вами сегодня после обеда на бульварах, в Café de la Paix, хоть под дождиком. Но вместо этого вечером поедем с Рамат-Ган с Евой Ефимовной на собрание китайских, т.е. дальневосточных евреев, где будет человек триста и разнообразная программа. 
Как прошла Conférence Amicale? [6] Видели ли Бор. Зайцева? Очень Вам хочется видеть Хрущева в Нью-Йорке? Вот увидите, он еще помирится с Эйзенхауэром, - но не Терапиано с Корвин-Пиотровским! [7]

Сердечно Вас обнимаю и непременно жду через год снова. Вот когда удастся Еве Еф<имовне> показать Вам ее хозяйские таланты, а то в этом году Вы у нас промелькнули, как метеор!

Ваш

Ю. Марголин

1. Залман Шазар (собств. Шнеер Залман Рубашов, 1889-1974), израильский государственный и общественно-политический деятель, третий президент страны (1963-1973), писатель, поэт, публицист. Марголин посвятил ему специальный очерк, см. Ю. Марголин, Тель-Авивский блокнот, «Новое русское слово» 1963, № 18342, 29 мая, сс. 2, 4.

2. Имеется в виду обращение Марголина к Шазару, обладавшему авторитетом и влиянием во властных структурах, по поводу застрявшей в бюрократических дебрях Еврейской повести.

3. Букв.: «высокочтимый мною человек» (обращение на высококнижном иврите).

4. Имеется в виду Мария Самойловна Цетлина (урожд. Тумаркина, 1882-1976), общественный деятель, издатель, меценат; жена поэта, прозаика, литературного критика, переводчика, редактора, издателя и общественного деятеля Михаила Осиповича Цетлина (1882-1945); Цетлина приходилась Вишняку двоюродной тетей.

5. Сергей Акимович Водов (1898-1968), журналист, один из основателей парижской эмигрантской газеты «Русская мысль» (с 1954 г. до конца жизни ее редактор), в которой сотрудничал Марголин.

6. Conférence Amicale — дружеская конференция (фр.).

7. Отношения двух живших в Париже эмигрантских поэтов - Юрия Константиновича Терапиано (1892-1980) и Владимира Львовича Корвина-Пиотровского (собств. Пиотровский, 1891-1966), отличались известной конфронтацией, о чем первый писал в своих воспоминаниях о втором (Ю. Терапиано. Литературная жизнь русского Парижа за полвека (1924-1974): Эссе, воспоминания, статьи, Альбатрос-Третья волна, Париж-НьюЙорк 1987, с. 239):

В натуре Корвин-Пиотровского, а не только в его творчестве, уживались большие противоположности. 
Начав подписываться после войны «своей полной», как он говорил, «фамилией Корвин-Пиотровский» и надев на руку гербовый перстень, он всюду и всем с гордостью рассказывал историю своего рода, ведущего начало от римского полководца, а затем от венгерских королей, и писал о себе:

...Потомок славы европейской. Венгерских и иных корон..., хотя «слава» и «корона» потомства иметь не могут.

В своих письмах - форме, предполагающей камерность и непубличность, Терапиано позволял себе более резкие выпады против мистифицированной родовитости Пиотровского. Так, в письме к Игорю Чиннову от 18 декабря 1962 г. он приводил посвященную ему следующую ядовитую эпиграмму (Письма запрещенных людей:Литература и жизнь в эмиграции: 1950-1980-е годы: По материалам архива И.В. Чиннова, сост. О.Ф. Кузнецова, ИМЛИ РАН, Москва 2003, с. 337):

Потомок славы европейской,

Венгерской и других корон,

Ты не «сошел в квартал еврейский»,

А из квартала вышел вон.

По-видимому, автором приведенной эпиграммы явился сам Терапиано. Строчка - «Ты не 'сошел в квартал еврейский'» целится в следующее место из поэмы Корвин-Пиотровского Возвращение (Вл. Корвин-Пиотровский, Поражение: Поэмы и стихи о России, Рифма, Париж 1960, с. 52):

Наследник славы европейской,

Венгерской и иных корон,

И я сошел в вертеп еврейский

За право умирать, как он.

А в письме к другому своему корреспонденту, Владимиру Маркову, тот же Терапиано 7 августа 1960 г. признавался (Если чудо вообще возможно за граничей... // Эпоха 1950-х гг. впереписке русских литераторов-эмигрантов, сост., предисл. и примеч. О.А. Коростелева, Библиотека-фонд «Русское Зарубежье»: Русский путь, Москва 2008, с. 315):

Я не терплю в П<иотровском> того, что он, прежде всего, пошлый и плоский человек. Будучи действительно артиллерийским прапорщиком военного времени после революции, он держит себя как «боевой офицер». Будучи (как все давно его знающие утверждают) евреем, он сфабриковал себе громкую фамилию и постоянно докучает всем, рассказывая о древности рода К<орвин> П<иотровских $>$, «потомков славы европейской, венгерской и иных корон». 
О той части баталии между Терапиано и Корвин-Пиотровским, которая была скрыта в частных письмах, Марголин, конечно, знать не мог, но за полемикой, ведущейся в открытой печати, он следил внимательно. В данном случае он имеет в виду их столкновение на страницах парижской «Русской мысли»: в рецензии на 4-ю книгу альманаха «Мосты» (1960), в которой были напечатаны три рассказа Корвин-Пиотровского, Терапиано отметил некоторые «стилистические небрежности» автора (1960, № 1564, 13 августа, с. 6-7); Корвин-Пиотровский в своем ответе критику этот выпад парировал (там же, № 1570, 27 августа, с. 7), на что последовала новая реакция рецензента (там же, с. 6-7).

\section{References}

Amfiteatrov, Alexander V. "'Zhili-byli tri sestry' (Pamiati Yek. P. Letkovoi)." Segodnia, no. 167, June 20, 1937: 4 [Амфитеатров, Александр В. "ЖЖили-были три сестры' (Памяти Ек.П. Летковой)", Сегодня, по. 167, 20 июня, 1937: 4].

A. G. <Aronson, G.> "Na vechere Yu.B. Margolina." Novoe russkoe slovo, no. 15005, May 27, 1953: 3 [А. Г. <Аронсон, Г.> "На вечере Ю.Б. Марголина." Новое русское слово, по. 15005, 27 мая, 1953: 3].

Aronson, Grigory Y. "'Opyty'. Kniga vtoraya." Novoe russkoe slovo, no. 15177, November 15, 1953: 8 [Аронсон, Григорий Я. “'Опыты'. Книга вторая." Новое русское слово, по. 15177, 15 ноября, 1953: 8].

Aronson, Grigory Y. Review of Yevreiskaya povest' by Yuly Margolin, Novyi zhurnal, no. 66, 1961: 283-285 [Аронсон, Григорий Я. Рецензия на Еврейскую повесть Ю. Марголина, Новый журнал, кн. 66, 1961: 283-285].

Dymov, Osip. I Remembered and Wanted to Relate...: From the Memoir and Epistolary Heritage: in two vols, vol. 2: Friends and Fellow Artists. Compilation and commentaries by V. Khazan. Jerusalem: The Hebrew University of Jerusalem; Center of Slavic Languages and Literatures, 2011 [Дымов, Осип. Вспомнилось, захотелось рассказать...: Из мемуарного и эпистолярного наследия, в 2-х томах, т. 2: В дружеском и творческом кругу Дымова. Составление и комментарий В. Хазана. Jerusalem: The Hebrew University of Jerusalem; Center of Slavic Languages and Literatures, 2011].

'Esli chudo voobsche vozmozhno za granitsei...': Epokha $1950^{\text {th }}$ v perepiske russkikh literatorov-emigrantov / Sostavlenie, predislovie i primechaniya by O.A. Korostelev. Moscow: Biblioteka-fond 'Russkoe zarubezhie'; Russkiy put', 2008 ['Если чудо вообще возможно за границей...': Эпоха 1950-х г2. в переписке русских литераторовэмигрантов. Составление, предисловие и примечания О.А. Коростелева. Москва: Библиотека-фонд 'Русское Зарубежье': Русский nymb, 2008]. 
Gul', Roman B. la unes Rossiyu: Apologiya emigratsii, v 3-kh tomakh, t. 1: Rossiya i Germaniya. Moscow: Yu.S.G.-Press, 2001 [Гуль Роман Б. Я унес Россию: Апология эмиграции, т. 1: Россия в Германии. Москва: Ю.С.Г.-ПРЕСС, 2001].

Heavy Burden of Responsibility for the Country, part 1: Russian Political Émigrés and Eretz Israel. Edited by V. Khazan. Jerusalem: The Hebrew University of Jerusalem, 2020 (Eretz Israel and the Russian Émigrés in Europe: Contacts, Connections, Communications, Interactions (19191939), vol. II).

Khazan, Vladimir I. Pinhas Rutenberg: Ot terrorista k sionistu: Opyt identifikatsii cheloveka, kotoryi delal istoriyu, v 2-kh tomakh. Jerusalem: Gesharim; Moscow: Mosty kul'tury, 2008 [Хазан, Владимир И. Пинхас Рутенберг: Om террориста к сионисту: Опыт идентификации человека, который делал историю, в 2-х томах. Иерусалим: Гешарим; Москва: Мосты культуры, 2008].

Khazan, Vladimir I. "Mat' Mariia: izrail'skie otzvuki tragicheskoy sud'by." Unacknowledged Legislators: Studies in Russian Literary History and Poetics in Honor of Michael Wachtel. Ed. by L. Fleishman <et al.>. Peter Lang, 2020 (Stanford Slavic Studies, vol. 50): 897-978. [Хазан, Владимир И. "Мать Мария: израильские отзвуки трагической судьбы." Unacknowledged Legislators: Studies in Russian Literary History and Poetics in Honor of Michael Wachtel. Ed. by L. Fleishman <et al.>. Peter Lang, 2020 (Stanford Slavic Studies, vol. 50): 897-978].

Korvin-Piotrovsky, Vladimir L. Porazhenie: Poemy i stikhi o Rossii. Paris: Rifma, 1960 [Корвин-Пиотровский Владимир Л. Поражение: Поэмы и стихи о России. Париж: Рифма, 1960].

Korvin-Piotrovsky, Vladimir L. "Otvet Yu.K. Terapiano." Russkaia mysl', no. 1570, August 27, 1960: 7 [Корвин-Пиотровский, Владимир Л. “Ответ Ю.К. Терапиано." Русская мысль, no. 1570, 27 августа, 1960: 7].

Makovsky, Sergei K. Portrety sovremennikov. New York: Izd-vo im. Chekhova, 1955 [Маковский, Сергей К. Портреты современников. НьюЙорк: Изд-во им. Чехова, 1955].

Makovsky, Sergei K. Na Parnase 'Serebrianogo veka'. Munich: ZOPE, 1962 [Маковский, Сергей К. На Парнасе 'Серебряного века'. Мюнхен: ЦОПЭ, 1962].

Makovsky, Sergei K. "Nikolai Gumilev po lichnym vospominaniam sovremennikov." Novyi zhurnal, no. 77, 1964: 157-189 [Маковский, Сергей К. "Николай Гумилев по личным воспоминаниям." Новый журнал, no. 77, 1964: 157-189].

Margoline, Jules. La condition inhumaine: Cinq ans dans les camps de concentration Sovietiques. Traduit par N. Berberova et Mina Journot. Paris: Calmann-Levi, 1949.

Margolin, Yuly B. Puteshestvie v stranu Ze-Ka. New York: Izd-vo im. Chekhova, 1952 [Марголин, Юлий Б. Путешествие в страну Зе-Ка. НьюЙорк: Изд-во им. Чехова, 1952].

Margolin, Yuly B. "Galia." Novyi zhurnal, no. 33, 1953: 107-123 [Марголин, Юлий Б. "Галя." Новый журнал, no. 33, 1953: 107-123].

Margolin,YulyB."Nonomnismoriar."Novyizhurnal,no.35, 1953:59-71 [Mapголин,Юлий Б. “Non omnis moriar." Новыйжурнал, no. 35, 1953:59-71]. 
Margolin, Yuly B. "Do We Leave the Russian Jews to Their Fate? (The Face Extinction, Unless)." Commentary, vol. 16, no. 4, October, 1953: pp. 321-327].

Margolin, Yuly B. "O Izhi." Opyty, no. 2, 1953: 88-99; no. 8, 1957: 118-25 [Марголин, Юлий Б. "О лжи." Опыты, no. 2, 1953: 88-99; no. 8, 1957: 118-125].

Margolin, Yuly B. "Ivan Alexandrovich Kuznetsov." Literaturnyi sovremennik, <no 1>, 1954: 147-153 [Марголин, Юлий Б. “Иван Александрович Кузнецов." Литературный современник, <по. 1>, 1954: 147-153].

Margolin, Yuly B. "V gostiakh u Xenii." Novoe russkoe slovo, no. 15765, June 26, 1955: 3 [Марголин, Юлий Б. "В гостях у Ксении." Новое русское слово, nо 15765, 26 июня, 1955: 3].

Margolin, Yuly B. "Mas le-avar." Haboker, no 6682, November 8, 1957: 6.

Margolin, Yuly B. "O svobode." Grani, no. 34/35, April-September, 1957: 305-335; no. 36, October-December: 211-223 [Марголин, Юлий Б. “О свободе." Грани, nо. 34/35, апрель-сентябрь, 1957: 305-35; no. 36, октябрь-декабрь: 211-223].

Margolin, Yuly B. "Istoriia odnogo neschastia." Novoe russkoe slovo, no. 16332, March 16, 1958: 2, 7 [Марголин, Юлий Б. "История одного несчастья." Новое русское слово, nо. 16332, 16 марта, 1958: с. 2, 7].

Margolin, Yuly B. “O Boge velikom." Vozdushnye puti, vol. 1, 1960: 259-282 [Марголин, Юлий Б. "О Боге великом." Воздушные пути, вып. 1, 1960: 259-282].

Margolin, Yuly B. Yevreiskaya povest'. Tel Aviv: Ma'ayan, 1960 [Марголин, Ю. Еврейская повесть. Тель-Авив: Мааян, 1960].

$<$ Margolin, Yuly B.> Galin, A. "'Proshloe' o proshlom." Vestnik Izrailia, no. 36, 1962: 33 [<Марголин, Юлий Б.> Галин, А. "'Прошлое о прошлом'." Вестник Израиля, nо 36, 1962: 33].

Margolin, Yuly B. "Tel-Avivsky bloknot." Novoe russkoe slovo, no. 18342, May 29, 1963: 2, 4 [Марголин, Юлий Б. "Тель-Авивский блокнот." Новое русское слово, по. 18342, 29 мая, 1963: 2, 4].

Margolin, Yuly B. "Uroki proshlogo." Novoe russkoe slovo, no. 18277, March 25, 1963: 2 [Марголин, Юлий Б. "Уроки прошлого." Новое русское слово, по. 18277, 25 марта, 1963: 2].

Margolin, Yuly B. "Raspad." Chetyre stat'i. Tel Aviv: MAOZ, 1971 [Марголин, Юлий Б. “Распад." Четыре статьи. Тель-Авив: МАОЗ (Общество борьбы за освобождение евреев из (ССР), 1971: 22-36].

Margolin, Yuly B. Povest' tysiacheletiy: szhatyi ocherk istorii yevreiskogo naroda. Tel Aviv: O-vo uvekovechivaniya pamiati d-ra Yliya Borisovicha Margolina, 1973 [Марголин, Юлий Б. Повесть тысячелетий: сжатый очерк истории еврейского народа. Тель-Авив: О-во увековечивания памяти д-ра Юлия Борисовича Марголина, 1973].

Margolin, Julius. Reise in das Land der Lager. Aus dem Russischen von Olga Radetzkaja. Berlin: Suhrkamp Verlag, 2013.

Margolin, Yuly B. Masa le-aretz haasirim. Transl. by Idit Shaked. Jerusalem: Karmel, 2013.

Margolin, Yuly B. Puteshestviyev stranu Ze-Ka, v2-kh knigakh. Tel Aviv: Jabotinskylnstitute,2017[Марголин,ЮлийБ.Путешествиевстранузека, в 2-х книгах. Тель-Авив: Институт Жаботинского в Израиле, 2017]. 
Oren, Mordechai. Jews, Arabs and British in Palestine: A Left Socialist View (London: Kibutz Artzi Hashomer Hatzair, 1936.

Pis'ma zapreschennykh liudei: Literatura izhizn'v emigratsii: 1950-1980 ${ }^{\text {th }}$ :Po materialam ahchiva I.V. Chinnova. Sostavitel' O.F. Kuznetsova. Moscow: IMLI RAN, 2003 [Письма запрещенных людей: Литература и жизнь в эмиграции: 1950-1980-е годы: По материалам архива И.В. Чиннова. Составитель О.Ф. Кузнецова. Москва: ИМЛИ РАН, 2003].

Tatida. Vos'mistishiya. Berlin, 1924 [Татида. Восьмистишия. Берлин, 1924].

Terapiano, Yury K. Review of almanac Mosty (vol. 4, 1960), Russkaya mysl', no. 1564, August 13, 1960: 6-7 [Терапиано Юрий К. Рецензия на альманах Мосты (кн. 4, 1960), Русская мысль, nо. 1564, 13 августа, 1960: 6-7].

Terapiano, Yury K. "Vynuzhdennyi otvet." Russkaya mysl', no. 1570, August 27, 1960: 6-7 [Терапиано Юрий К. "Вынужденный ответ." Русская мысль, no. 1570, 27 августа, 1960: 6-7].

Terapiano, Yury K. Literaturnaia zhizn' russkogo Paris za polveka (19241974): Esse, vospominaniya, stat'i. Paris, New York: Albatros-Tretia volna, 1987 [Терапиано Юрий К. Литературная жизнь русского Парижа за полвека (1924-1974): Эссе, воспоминания, статьи. Париж, Нью-Йорк: Альбатрос-Третья волна, 1987].

Vishniak, Mark V. "Israel (Iz vpechatleniy)." Novyi zhurnal, no. 26, 1951: 217236 [Вишняк, Марк В. “Израиль (Из впечатлений)”, Новый журнал, no. 26, 1951: 217-236].

Vishniak, Mark V. Review of Puteshestviye $v$ stranu Ze-Ka by Yu. Margolin, Novyi zhurnal, no. 31, 1952: 320-322 [Вишняк Марк В. Рецензия на Путешествие в страну Зе-Ка Ю. Марголина, Новый журнал, nо. 31, 1952: 320-322].

Vishniak, Mark V. Dan' proshlomu. New York: Izd-vo im. Chekhova, 1954 [Вишняк, Марк В. Дань прошлому. Нью-Йорк: Изд-во им. Чехова, 1954].

Vishniak, Mark V. Gody emigratsii, 1919-1969. Paris-New-York (Vospominaniya). Stanford: Stanford University: Hoover Institution Press, 1970 [Вишняк, Марк В. Годы эмиграции, 1919-1969. Париж-Нью-Йорк (Воспоминания). Stanford: Stanford University: Hoover Institution Press, 1970].

Xenia. "Shalosh mehaphaniyot yehudiyot." Heavar, vol. 5, 1957: 104-115.

Zlobin, Vladimir A. Tiazhelaya dusha: Literaturnyi dnevnik, vospominaniya, stat'i, stikhotvoreniya. Red. L.M. Suris. Moscow-Berlin: Direkt-Media, 2016 [Злобин В.А. Тяжелая душа:Литературный дневник, воспоминания, статьи, стихотворения. Под ред. Л. М. Суриса. МоскваБерлин: Директ-Медиа, 2016].

Zoschenko, M. Povesti i rasskazy. New York: Izd-vo im Chekhova, 1952 [Зощенко, М. Повести и рассказы. Нью-Йорк: Изд-во им. Чехова, 1952]. 